\title{
Bariátriai mútétekre való pszichológiai alkalmasság felmérése
}

\author{
Tisljár-Szabó Eszter dr. - Tisljár Roland dr. \\ Debreceni Egyetem, Népegészségügyi Kar, Magatartástudományi Intézet, Debrecen
}

\begin{abstract}
A kóros elhízás és a kezelésére alkalmazott bariátriai mütétek száma jelentős napjainkban. Bár számos ismeretünk van arra vonatkozóan, hogy a pszichés állapot (depresszió, szorongás, evészavar stb.) befolyásolhatja az orvosi teammel való együttmúködést, a mútét kimenetelét, rövid és hosszú távú hatásosságát, Magyarországon nincs egységes protokoll vagy ajánlás a bariátriai beavatkozásokra várók pszichológiai szúrésére. Így - ha az orvos vagy a kórház mégis feltételként szabja a pszichológusi szakvéleményt - sem az orvos számára nem egyértelmú, hogy mit várhat egy ilyen szakvéleménytől, sem a pszichológusok nincsenek teljesen tisztában azzal, hogy melyek a pácienssel átbeszélendő területek. A jelen tanulmány röviden áttekinti a leggyakrabban alkalmazott mútéti eljárásokat, majd részletesen ismerteti a New Orleans-i Ochsner Klinikán 2009-ben kidolgozott protokollt. Ez alapján a pszichológiai interjú fő területei: a mútéttel kapcsolatos elvárások és a döntés oka (I.), a súly- és fogyástörténet (II.), az étkezési szokások (III.), a mütéttel kapcsolatos ismeretek (IV.), a társas támasz (V.), a pszichiátriai kórtörténet és a jelenlegi állapot (VI.). A szerzók az eredeti protokollt újabb, frissebb kutatásokkal, állásfoglalásokkal és példákkal egészítették ki.
\end{abstract}

Orv Hetil. 2019; 160(12): 448-455.

Kulcsszavak: bariátriai beavatkozás, pszichológiai felmérés, elhízás, pszichoszociális tényezók

\section{Psychological assessment of candidates for bariatric surgery}

Nowadays, the number of bariatric surgery for treating morbid obesity is significant. There is strong evidence about the influence of mental state (depression, anxiety, eating disorder, etc.) on patient's cooperation with the medical team and the outcome, and on the short or long-term effectiveness of surgery. However, no protocol or recommendation exist for screening patients before bariatric procedures in Hungary. Thus, even if the surgeon or the hospital requires psychological expertise, neither doctors are familiar with the expectable results of such an expertise, nor psychologists know exactly what the most important areas are to talk through with patients. This article shortly reviews the mostly used bariatric surgery procedures and presents a protocol that was developed by the Ochsner Clinic, New Orleans in detail. Based on the protocol, the core parts of the psychological interview are the following: reasons for seeking surgery (I.), weight and diet history (II.), current eating behaviors (III.), understanding of the surgery and its associated lifestyle changes (IV.), social supports (V.), and history and psychiatric symptoms (current and past) (VI.). The original protocol was completed with newer, more recent studies, statements, and with examples by the authors.

Keywords: bariatric procedures, psychological assessment, obesity, psychosocial factors

Tisljár-Szabó E, Tisljár R. [Psychological assessment of candidates for bariatric surgery]. Orv Hetil. 2019; 160(12): $448-455$.

(Beérkezett: 2018. szeptember 24.; elfogadva: 2018. október 31.)

\section{Rövidítések}

$\mathrm{BMI}=($ body mass index $)$ testtömegindex PTSD $=($ posttraumatic stress disorder) poszttraumás stresszzavar; WHO = (World Health Organization) Egészségügyi Világszervezet
A WHO 2016. évi adatai alapján [1] Magyarországon a túlsúlyos $\left(\mathrm{BMI}>25 \mathrm{~kg} / \mathrm{m}^{2}\right)$ felnőttek aránya $61,6 \%$, ezen belül a felnőtt lakosság 26,4\%-a elhízott, obes (BMI >30 $\left.\mathrm{kg} / \mathrm{m}^{2}\right)$. 
Önmagában a kalóriabevitel csökkentése, a testmozgás növelése, az életmód megváltoztatása megfelelő motiváció mellett hatásos lehet, ugyanakkor számos esetben indokoltnak tünik bariátriai beavatkozás elvégzése. Ilyen modern bariátriai beavatkozás például a gyomorbypass, amikor a vékonybél felszívófelületének egy részét kiiktatják, s ennek révén az elfogyasztott ételnek csak kis része szívódik fel. 2001 óta a leggyakrabban a gyomorgyưrüt alkalmazzák: egy szilikongyưrü segítségével a gyomrot homokóraszerűre alakítják, akadályt képezve ezzel a táplálék útjának. A sleeve gastrectomia (csőgyomorképző mütét) a kedvezőbb szövődményrátája miatt az utóbbi években kezdett népszerü lenni. Ennek során a gyomor úrtartalmát jelentős mértékben, körülbelül 85\%-kal csökkentik, ezáltal hamarabb kialakul a teltségérzet $[2,3]$. Az említett beavatkozások gyors és jelentős fogyást eredményeznek, a testsúlyfelesleg 30-70\%-a eltünhet másfél-két év alatt, ezáltal megszűnhetnek a társuló betegségek is, úgymint diabetes mellitus, magas vérnyomás, alvási apnoe [2]. A páciensek egy részének sikerül az életmódváltás, és a gyors fogyás után meg tudják tartani vagy tovább tudják csökkenteni testsúlyukat. Ugyanakkor egyes tanulmányok arról számolnak be, hogy hosszú távon sokak számára nem tartható fenn a lefogyott állapot. Lauti és $m t s a i$ [4] szisztematikus áttekintése egyrészt felhívja a figyelmet arra, hogy a szakirodalomban nem megfelelően definiált és ezért nehezen mérhető és publikálható a „nem megfelelő mértékű fogyás”, az „újbóli hízás” (a lefogyott állapothoz képest), a „visszahízás” fogalma és azon vizsgálati személyek száma, akiknél nem mondható teljesen sikeresnek a mütéti beavatkozás. Lautiék áttekintése alapján azonban hat évvel a mütét után 75,6\% is lehet a fenti kategóriákba esők aránya. Flølo és mtsai [5] vizsgálatában a bariátriai műtét után 5 évvel 39\% volt azok aránya, akiknek a kezdeti állapothoz képest alig vagy nem az elvárható mértékben csökkent a testsúlyuk (a definíció és a számítás pontos módját lásd [5]). Az okok között táplálkozási, hormonális, pszichés, inaktivitási és anatómiai/ mútéti faktorok is szerepelhetnek [4]. Mivel a pszichés tényezők szerepe jelentős $[6,7]$, a siker megjóslásában és a negatív befolyásoló faktorok feltárásában és módosításában fontos szerepe lehet a pszichológiai szürésnek.

Bár hazánkban is nő a bariátriai mútéteken átesettek száma, és egyre több klinika javasolja vagy írja elő páciensei számára a mútét előtti pszichológiai konzultációt, Magyarországon erre vonatkozóan nincs kidolgozott protokoll. Nemzetközi szinten is inkább ajánlásokkal találkozunk [8].

Ennek a cikknek célja tehát, hogy ismertesse a bariátriai mûtétek előtt álló páciensek pszichológiai szűrésének egy lehetséges protokollját, amelyet az Ochsner Klinikán dolgoztak ki 2009-ben [9]. A szerzők tudomása és véleménye szerint ez a legalaposabb, legrészletesebb leírás, amely a gyakorlatban jól használható. Az ismertetést kiegészítettük újabb kutatásokkal, egy frissebb, kevésbé részletes, ugyanakkor határozottabb állásfoglalásokat tartalmazó tanulmánnyal [10] és saját tapasztalattal.

\section{A protokoll ismertetése}

Az Ochsner Klinika protokollja szerint a pszichológiai felmérésnek a következőkre kell kitérnie: a mütéttel kapcsolatos elvárások, a döntés oka (I.), súly- és fogyástörténet (II.), étkezési szokások (III.), a mútéttel kapcsolatos ismeretek (IV.), társas támasz (V.), a pszichiátriai kórtörténet és a jelenlegi állapot (VI.).

A pszichológus általában nyitott kérdéseket használ, a pácienst hagyjuk beszélni, a saját szavaival válaszolni, így a különböző témák gyakran nem válnak el egymástól mereven. Például amikor a mütét választásának okára kérdezünk rá, elképzelhető, hogy a súlytörténetével kapcsolatban is átad majd információkat a beteg.

\section{A mütét választásának okai}

A pszichológiai konzultációnak ki kell térnie arra, hogy a betegek hogyan jutottak arra az elhatározásra, hogy megmüttessék magukat, mivel indokolják, hogy orvosi beavatkozás révén szeretnének lefogyni, és miért pont most határozták el magukat. Az is lényeges kérdés, hogy mit vár a személy a mútéttől.

Magától a fogyástól a legtöbben az egészségi állapot javulását, a mobilitás növekedését, több energiát remélnek. Egy magyar kutatás szerint [11] a nők a férfiaknál sokkal inkább azt várják, hogy a súlycsökkentést követően javul majd megjelenésük, vonzóságuk, növekszik önbizalmuk, valamint hogy bátrabbak lesznek a társas interakciókban.

Problematikus lehet, ha a személy valamilyen külső tényezőt (például „a munkám miatt kell”) vagy egy személyt nevez meg indokként (például „a férjemnek fontos, ő szeretné, hogy lefogyjak”), hiszen ilyenkor teljesen hiányozhat a belső motiváció, amely azonban nagyon fontos a későbbiekben, a fogyás fenntartásában. Szintén nehézséget okozhat, ha a páciens túl nagy hangsúlyt fordít a testi megjelenésre, vagy irreális elvárásokat fogalmaz meg azzal kapcsolatban, hogy milyen gyorsan vagy hány kilogrammra szeretne lefogyni, illetve hogy milyen lesz az alakja a mütétet követően. Az irreális elvárások növelhetik a mütét utáni csalódottságérzés valószínüségét, amely megjelenhet az orvos hibáztatásában, az együttmúködés megszakadásában, másrészt lehangoltsághoz, depresszióhoz vezethet.

A pszichológus feladata a fenti témák átbeszélése, a páciens elvárásainak reális irányba terelése és a belső motiváció növelése.

\section{Súly-és fogyástörténet}

A legtöbb betegre nem igaz, hogy a bariátriai mútét lenne az első próbálkozás a fogyásra. Sokkal inkább az jellemző, hogy hosszabb-rövidebb, hízással és fogyással töltött időszakok jellemzik az elmúlt éveiket, évtizedeiket. A súlyuk sokaknak - kisebb vagy nagyobb mérték- 
ben - ingadozó, és általában több módszerrel is megpróbálták már korábban csökkenteni testsúlyukat.

A pszichológiai konzultáció során érdemes egy idővonal segítségével átvenni a páciens súlyának és fogyási kísérleteinek alakulását. Az idővonal tartalmazza, hogy mióta vannak a betegnek problémái a súlyával (például „már gyerekként és serdülőként is duci voltam”, vagy „a második gyerekem születése után híztam meg ennyire”). Ebből az obesitas esetleges családbeli halmozódásáról is információkat kaphatunk.

Az idővonal segítségével a pácienssel átbeszéljük, hogy a súlygyarapodás, illetve a súlycsökkenés milyen életeseményekkel kapcsolható össze (párkapcsolati válság, házasságkötés, kollégiumba kerülés, terhesség stb.). Rávilágíthatunk az életbeli nehézségek és a testsúly változásának esetleges összefüggéseire. Átbeszéljük, hogy vajon mi volt a gátja annak, hogy megtartsa a normál testsúlyú állapotot, és hogy milyen esetleges negatív érzések (például szégyen) kapcsolódnak a kudarcokhoz. A pszichológus empatikus hozzáállása segíthet a páciensnek felismerni, hogy az érzelmek, a viselkedés (evés, mozgás) és a testsúly összefüggésben állhatnak egymással, egymást befolyásolják.

Kitérünk arra is, hogy milyen módszerekkel (diéta, mozgás, táplálékkiegészítők, természetgyógyász stb.) próbált meg korábban lefogyni a személy, és mennyire voltak sikeresek ezek a próbálkozások. A pszichológus elfogadó attitűddel viszonyul a személy által próbált módszerekhez, de itt is a realitást képviseli.

Ha az derül ki, hogy a személy korábban nem próbálkozott még semmilyen súlycsökkentő módszerrel, az az énerő és a belső motiváció hiányára utalhat. Ilyenkor mindenképpen arra motiváljuk, hogy a mútét előtt próbáljon ki még valamilyen módszert, hiszen ezek jóval kisebb kockázattal járhatnak, mint a mütét, és alkalmasak lehetnek az énerő növelésére.

\section{Étkezési szokások és a testmozgás}

Az, hogy a páciens hogyan táplálkozik, információt szolgáltathat arról, hogy mennyire motivált a fogyásban, mennyire érzi a változás szükségességét, illetve hogy az elhízás hátterében megfigyelhető-e evészavar.

Ideális esetben a bariátriai műtét előtt a betegek már számos információval rendelkeznek a helyes táplálkozásról, és túl vannak több konzultáción is, amelyen dietetikusuk, táplálkozási tanácsadójuk, orvosuk javasolta nekik, hogy a mütét érdekében kezdjék az étkezési szokásaik megváltoztatását. Az, hogy a beteg milyen mértékben képes betartani ezeket az utasításokat, jól jelzi előre a mútét utáni komplikációk és a noncompliance valószínúségét. A pszichológus szerepe az lehet, hogy egyrészt hangsúlyozza a fenti konzultációkon elhangzottak fontosságát, másrészt megvizsgálja, hogy az információkat a beteg megértette-e, helyesen értette-e. Ha kiderül, hogy nem világosak a páciens számára az összefüggések, javaslatok, a pszichológus újbóli dietetikai tanácsadást javasol.

Érdemes feltárni az étellel és az étkezéssel kapcsolatos hiedelmeket, rögzült mintázatokat is. Az olyan mondatok, elképzelések, mint például „ételt nem hagyunk a tányéron, amit kiszedtél, meg kell enni”, „fogyjon el, amit megfőztem”, „régen is kenyeret ettek szalonnával, mégsem híztak meg", hozzájárulhatnak a nem megfelelő táplálkozás fennmaradásához. Ezen téves hiedelmek és szokások módosításával nagyobb lesz a későbbiekben a fogyásnak/nem visszahízásnak a valószínưsége. Bár a rögzült hiedelmek megváltoztatása hosszabb időbe telhet, jó, ha a pszichológus már a mütét elött rálát arra, hogy menynyiben a téves elképzelések vezettek az elhízáshoz.

A modellkövetés vagy az utánzás, gyermekkorban a szülői helytelen étkezési magatartás automatikus követése vagy a szülők étellel való nevelési magatartásának hatása szintén jelentős. Az étel révén történő büntetés ( „addig nem mehetsz játszani, amíg nem etted meg az ételt”) vagy jutalmazás („az ötös dolgozatért jár egy fagyi”) a kondicionálás mechanizmusán keresztül befolyásolja ételpreferenciánkat, étkezési szokásainkat [12].

A bariátriai mútétre váró betegek között nem ritka az evészavar. Kutatások és összefoglalók 5-27\% közé teszik például a falásroham-zavarosok arányát [13-15]. A betegek körében megjelenik még az éjszakaievés-zavar, amelyre az jellemző, hogy a személy vacsora után, éjszaka, alvásból felébredve nagy mennyiségú táplálékot fogyaszt. Bár úgy tünhet, hogy a falásrohamzavar vagy az éjszakaievés-zavar egyértelműen okozhatja az elhízást, kutatások azt mutatják, hogy az összefüggés nem nyilvánvaló. Hiszen a falásrohamban szenvedőknek egy része nincs elhízva [16].

Az eredmények nem egyértelmüek azzal kapcsolatban sem, hogy a falásrohamzavar milyen mértékben befolyásolja a bariátriai műtét sikerességét $[17,18]$. Egyes kutatások azt találták, hogy a falásrohamok megszünnek a mútét után, vagy hogy a falásrohamzavar megléte a mütét előtt nem feltétlenül gátja a mútét utáni megfelelő súlycsökkenésnek. Mások arra hívják fel a figyelmet, hogy a mütét után a falásrohamban szenvedőknél a kezdeti súlycsökkenés után megnő a súlyvisszaszedés valószínűsége. Ezeknek a betegeknek érdemes pszichoterápiát javasolnunk, ha a falásrohamok gyakoriak, vagy ha a beteg aggódik amiatt, hogy a mútét után mennyire lesz képes kontrollálni a rohamokat.

A protokoll szerint az egyedüli valódi kontraindikáció a mûtétre az evészavarok közül a bulimia, mivel a tápláléktól való megszabadulás önhánytatással vagy hashajtózással komoly egészségügyi kockázatot jelent, és növeli a komplikációk megjelenésének valószínúségét. Ha a mütét előtt fény derül a bulimia jelenlétére, a páciensnek érdemes kognitív viselkedésterápiát javasolni.

A legtöbb súlyosan obes páciens fizikailag inaktív, mivel a mozgás fájdalmas és megerőltető számukra. A korábbi mozgásszegény életmód természetesen hozzá is járulhatott az elhízás kialakulásához [19]. Az Ochsner 
Klinika protokollja alapján a pszichológusnak érdemes hangsúlyoznia, hogy hosszú távon a súlycsökkenés fenntartásához a fizikai aktivitás mindennapi rutinná válása elengedhetetlen.

A cikk szerzői a táplálkozás szerepét fontosabbnak tartják. Bár a testmozgásnak számos jótékony hatása van, és hozzájárul például az étvágyszabályozás, a cardiovascularis funkciók [20] és a hangulat javulásához is [21, 22], metaanalízisek azt találták, hogy a testmozgás önmagában nem feltétlenül okoz fogyást. A változás sok tényező függvénye, és nem szükségszerű következménye a mozgásnak [23-25]. Ugyanakkor bizonyos kutatások azt mutatják, hogy a fogyásprogramok hosszú távon sikeresebbek, ha a táplálkozás megváltoztatása mellett a rendszeres mozgás is beépül a páciensek életébe, mint amikor kizárólag az étkezési szokások megváltoztatásán van a hangsúly [23].

A betegeket tehát érdemes kikérdezni arról, hogy mit tudnak, mit gondolnak a fizikai aktivitásról, próbálkoztak-e eddig mozgás segítségével fogyni, szeretnének-e majd mozogni a mútét után, ha lefogynak. A pszichológus hangsúlyozza a testmozgás pozitív élettani hatásait, és motiválja a pácienst az aktív életmódra.

\section{A mütéttel kapcsolatos ismeretek}

Minden mütéti beavatkozás előtt szükséges, hogy a betegek aláírák a beleegyezô nyilatkozatot, amely számos információt tartalmaz. Bár a betegek minden esetben aláírásukkal tanúsítják, hogy végighallgatták, elolvasták és megértették, hogyan fog zajlani a mütét és a lábadozás időszaka, és a beavatkozás lehetséges következményeiről, kockázatairól is tudnak, kutatások azt mutatják, hogy még ha valóban megtörtént is a betegtájékoztatás, a betegek nem tudják pontosan felidézni az elhangzott vagy akár leírt információkat [26]. Egyes kutatások csak 25-29\%-os [27, 28] felidézésról írnak. Egy vizsgálatban [29] a betegeknek csak a 29,6\%-a mondta, hogy ténylegesen elolvasta a beleegyező nyilatkozatot, mielőtt aláírta volna azt.

A pszichológiai vizsgálat során megkérjük a beteget, hogy mondja el, mit tud a mütétről: mit tud arról, hogy az milyen kockázatokkal, milyen lehetséges kimenetelekkel járhat, milyen életmódbeli változások szükségesek a sikerhez. Ha a beteg nem tudja elmondani, hogy pontosan milyen típusú lesz a mútétje, mi fog vele történni a mütét során (például laparoszkópos mütét, gyomorgyürü, gastric bypass [gyomoráthidalás] vagy gastric sleeve mütét), a pszichológus javasolja, hogy menjen vissza a sebészhez konzultációra, olvassa el a kapott tájékoztatókat, és tegye fel kérdéseit orvosának. Ritkán az is előfordulhat, hogy a beteg kognitív képességeinek, intellektusának tesztelése szükséges annak felmérésére, hogy képes-e egyáltalán megérteni a beleegyező nyilatkozat tartalmát.

Hasznos lehet, ha a betegek részt vesznek csoportos foglalkozásokon, amelyeken olyan személyekkel beszél- gethetnek, akik már túl vannak a mütéten. Itt információkat szerezhetnek a mútét lefolyásáról és a mútét utáni tapasztatokról más betegek szemszögéből. A csoportos vagy az egyéni konzultáció során is fontos, hogy szóba kerüljön: a mútét nem mágikus eszköz, és nem fogja meggátolni a pácienseket abban, hogy egyenek. Lehet, hogy úgy érzik majd, hogy hamarabb jóllaktak, vagy csökken az éhségérzetük, de magát az evést nem gátolja meg a sebészi beavatkozás. Tehát minden esetben a beteg felelőssége, hogy ne egyen, ha nem éhes, és abbahagyja az evést, ha már úgy érzi, jóllakott (de ehhez az szükséges, hogy figyeljen a belső jelzéseire!). Ha ezt nem teszi, fennáll a mưtét utáni súlygyarapodás valószínüsége. A mútét tehát egy eszköz, amely abban segíti őket, hogy javítsanak egészségi állapotukon, ha megfelelően táplálkoznak.

\section{A társas támogatás feltérképezése}

A bariátriai mütétet választó páciensek életmódváltása nem izoláltan, hanem az őket körülvevő társas hálóban zajlik. A rokonok és a barátok támogathatják vagy éppen ellenezhetik is a mütétet, és fontos szerepet tölthetnek be a mütét utáni lábadozás alatti segítségnyújtásban is. Ha a beteg egy háztartásban él családtagjaival, azok étkezési szokásai, egészséges élethez való hozzáállása jelentős hatással bírhat a személy viselkedésére. A pszichológiai konzultáció során arra kérjük a pácienst, hogy beszéljen arról, kikkel él egy háztartásban, ők hogyan reagáltak a mütéttel kapcsolatos döntésére, milyenek az ő étkezési szokásaik, vannak-e súlyproblémáik.

Érdekes és új szempontok merülhetnek fel, ha a beteget megkérjük, gondoljon arra, hogy a mútétnek vajon milyen társas következményei lehetnek: ki hogyan fog reagálni a környezetében. Elképzelhető például, hogy egyesek negatív véleményt fognak mondani („így bárki le tud fogyni”), mások irigyek lehetnek és kerülhetik a pácienst, ha meglátják, hogy mennyit fogyott. Nehézségeket vagy kihívást jelenthet majd étterembe vagy nyaralni menni olyan személyekkel, akik még nem szokták meg, hogy a személy már nem annyit és másmilyen ételeket eszik, mint korábban. Negatív megjegyzések érkezhetnek azoktól, akik továbbra is egészségtelenül táplálkoznak. A pszichológusnak a konzultáció során érdemes egy-két példát említeni az esetleges negatív reakciókra vonatkozóan, és felmérni, hogy ilyen kihívást jelentő helyzetekben hogyan reagálna a páciens. Esetleg egy második konzultáció alkalmával megoldási stratégiákat lehet kidolgozni az ilyen helyzetekre. Ez segíthet megelőzni egy későbbi konfliktust.

\section{A pszichiátriai kórtörténet és a jelenlegi mentális állapot}

Több kutatás is kimutatta, hogy a bariátriai mútétre váró személyek között magas a pszichiátriai problémákkal 
küzdők aránya. Kalarchian és mtsai (2007) kutatásában [30] a mútétre váró személyek 38\%-a teljesítette valamilyen I-es tengelyes pszichiátriai zavar diagnosztikai kritériumait: 24\%-uk valamilyen szorongásos zavarban, 15,6\%-uk hangulatzavarban szenvedett, ebből 10,4\% depressziós volt. $29 \%$-uk pedig egy vagy több II-es tengelyes diagnózissal is rendelkezett, azaz a személyiségzavarok aránya is meglehetősen magas ebben a populációban. Más kutatások azt találták, hogy a mútét előtti pszichológiai vizsgálat idejében a betegek 23-47\%-a szedett valamilyen pszichotrop gyógyszert [17].

A pszichológiai vizsgálat célja tehát az is, hogy feltárja, van-e a páciensnek olyan pszichiátriai problémája, amely negatívan befolyásolná a mútétet vagy annak kimenetelét. Annak ellenére, hogy a depresszió mértéke magas ebben a populációban, önmagában nem jelent kontraindikációt a mútétre. Odom és mtsai (2010) [31] kutatásukban például azt találták, hogy a mütét előtt nagyobb mértékü depresszióval jellemezhető személyek kevésbé híztak meg a lefogyott állapothoz képest a mútét után átlag 28 hónappal. Ez az eredmény arra utal, hogy a depresszív hangulat az elhízásnak lehet következménye is, és a mütét nemcsak a testsúlyt csökkenti, de ennek révén a hangulatot is javítja [7, 30].

A depresszió kezelése a mútét előtt abban az esetben szükséges, ha a depresszió negatívan befolyásolja az orvossal való együttmúködést, például a beteg nem jelenik meg a konzultációkon, vagy ellenségesen viselkedik kezelőorvosával, ha öngyilkossági késztetései vannak, illetve ha bipoláris zavar vagy pszichózis feltételezhető. Ugyanakkor fontos tájékoztatni a betegeket arról, hogy a depresszió nemcsak a mútéttel kapcsolatban fontos tényező, de jelentős szenvedést és rossz életminőséget is jelent számukra, tehát ha a mütét után is fennáll, mindenképpen érdemes szakemberhez fordulniuk.

A depresszión kívül a szorongás is jelentős tényező a bariátriai mútétre váróknál $[7,18,30]$. A szorongás negatívan befolyásolja a mútét előtt vagy közvetlenül utána elhangzott információk megértését, valamint növeli annak valószínúségét, hogy a betegek intenzívebben monitorozzák testi érzeteiket. Ez ahhoz vezet, hogy túlzottan érzékenyek lesznek a legkisebb változásra is, és gyakrabban értékelik ezeket a változásokat negatívnak, így növekedhet a felesleges orvosi konzultációk száma.

Egy kutatásban [30] a bariátriai mútétre várók 32,6\%-a számolt be arról, hogy korábban volt olyan időszak az életükben, amikor kóros szerhasználat vagy -függőség jellemezte őket. Az alkohol- és drogfogyasztással kapcsolatos problémák pedig növelik a mütét után a visszahízás valószínúségét [31]. Ugyanakkor közvetlenül a mütét előtti felmérés során csak nagyon kevesen teljesítik a függöségek diagnosztikai kritériumait [30]. Ebben természetesen megjelenhet az is, hogy a betegek mindenképpen szeretnének megfelelni a mütét feltételeinek, így nem vallják be problémáikat. Elképzelhető azonban emellett az is, hogy mivel az ételfüggőség és a szerfüggőség hátterében részben hasonló mechanizmusok állnak
[32], ha mérséklődik a szerhasználat, az evéssel kapcsolatos problémák kerülnek elötérbe. Ez fordítva is igaz lehet: ha a mútét után a személy nem lehet függő az ételtől, vagy nem tudja azt stresszcsökkentő módszerként használni, újból vissza fog térni valamilyen szerre. Ugyanakkor ezeket a feltételezéseket nem támasztották alá egyértelmúen kutatások, így további vizsgálatok szükségesek az esetleges összefüggések feltárására.

Azokkal a páciensekkel, akik pszichiátriai kezelés alatt állnak és/vagy pszichotrop gyógyszert szednek, érdemes átbeszélni, hogy tájékoztatták-e pszichiáterüket, a gyógyszert felíró orvosukat a bariátriai mütétről, s neki mi volt a véleménye arról. Arra bátorítjuk őket, hogy mindenképpen tájékoztassák minden orvosukat az öszszes orvosi kezelésükről, beavatkozásról. Mivel az életmódváltás gyakran nagymértékű stresszel jár, a felmérés során a pszichológus arra motiválja a pácienst, hogy - ha nem kontraindikált - továbbra is folytassa az elkezdett gyógyszeres vagy pszichológiai kezelést, és ne hagyja abba akkor sem, ha kicsit jobban érzi magát, vagy elkezdett fogyni. Minden változásról konzultáljon orvosaival.

Klinikai megfigyelések, de egyes kutatások is arra utalnak, hogy a gyermekkori szexuális abúzus és az obesitas kapcsolatban vannak egymással (az áttekintéseket, metaanalíziseket lásd [33-36]). A szexuális zaklatás vagy erőszak áldozatai között nagyobb mértékű az elhízás, mint az ilyen élményektől mentes populációban. Másrészről: súlyosan elhízott személyek körében sokkal nagyobb arányban van jelen a gyermekkori szexuális zaklatás, mint a normál súlyú populációban $(25 \%$ versus $6 \%)$, és az abúzus az esetek nagy részében megelőzi az elhízás kezdetét; az elhízás hamarabb jelentkezik a gyermekkori szexuális bántalmazást elszenvedetteknél [37]. Más kutatások ugyanakkor nem találtak kapcsolatot a két jelenség között. Elképzelhető, hogy a korai ártalmas élmények és az obesitas a falásrohamzavar és egyéb érzelemszabályozási zavarokon mint mediáló tényezőkön keresztül kapcsolódnak össze. Egy másik megközelítés szerint az obesitas egy adaptív reakció a szexuális abúzusra, hiszen az elhízott testalkat kevésbé vonzó lehet a férfiak számára, és nagyobb erőt is képvisel, így védelmet nyújthat egy későbbi támadással szemben [33]. Az Ochsner Klinika protokollja alapján a pszichológiai konzultáció során érdemes feltárni a pácienst gyermekkorában ért ártalmas élményeket. A mütét következtében bekövetkező jelentős testsúlyvesztés ugyanis tudatosan vagy tudattalanul a korábbi állapotra és ezzel együtt az abúzusra emlékeztetheti a pácienst, erôs érzelmi reakciókat, akár PTSD-t kiváltva. Érdemes a pácienseket ezekről a témákról tájékoztatni, és arra biztatni, hogy keressenek segítséget a nehézségek feldolgozására.

$\mathrm{Az}$ említett pszichés problémák áttekintése után a pszichológus visszajelzést ad a fennálló zavaroknak az esetleges mútétre gyakorolt hatásáról, és ha szükséges, további pszichológiai konzultációs lehetőséget ajánl fel, vagy más pszichológushoz küldi tovább a pácienst. Bár a fenti problémák miatt közvetlenül csak ritkán szükséges 
a mütét elhalasztása, a páciens általános egészségi állapota és életminősége és a beavatkozás hosszú távú sikeressége végett is mindenképpen érdemes a pszichiátriai zavarok meglétének vizsgálata.

\section{Pszichológiai tesztelés}

Mivel a legtöbb kórházban - legalábbis külföldön - a bariátriai mútét feltétele a pszichológiai alkalmasság, a betegeken nagy a nyomás. A pszichológiai alkalmatlanság a mütét elhalasztását jelentheti, így a pácienseknek az az érdekük, hogy érzelmi nehézségeiket minimalizálják. Bár a pszichológus próbál olyan empatikus légkört teremteni, amelyben a betegek megnyílhatnak és őszintén beszélhetnek problémáikról, néhányan hajlamosak lehetnek magukat a valóságnál pozitívabb színben feltüntetni, bizonyos problémákat letagadni. A pszichológiai tesztek nem tudják garantálni az őszinteséget, de segíthetnek a hazugságok kiszűrésében, megerősíthetik vagy kiegészíthetik a korábbi beszélgetés alatt feltárt szubjektív adatokat, feltárhatják az esetleges pszichopatológiai tüneteket, személyiségzavarokat, pszichoszociális stresszorokat és a kezeléssel kapcsolatos későbbi nehézségeket, például nonadherenciát. A teszt kitöltése előtt arra bátorítjuk a pácienst, hogy őszintén válaszoljon a kérdésekre, valamint tájékoztathatjuk, hogy ezen a teszten nem lehet megbukni, tehát nem önmagában ennek az eredményén fog múlni a mútétre való alkalmasság.

Az Ochsner Klinika csapata az MMPI-2 (Minnesota Multiphasic Personality Inventory [38], illetve a Millon Behavioral Medicine Diagnostic [39] (idézi [9]) teszteket javasolja. Magyarországon hozzáférhetősége miatt a leggyakrabban az MMPI-teszt Pressing és Szakács [40] által standardizált változatát használjuk. A Millon Behavioral Medicine Diagnostic teszt magyar nyelven nem ér- hető el - 165 eldöntendő kérdésből áll, normaértékeit bariátriai betegekre is kidolgozták. A teszt rákérdez például a rizikóviselkedésekre, a megküzdésre, a fájdalomra, és megpróbálja megjósolni, hogy a pácienst mennyire fogja megviselni a beavatkozás, mennyire fog együttműködni orvosaival. A teszt egyelöre angol és spanyol nyelven érhető el. Bár hasznos eszköznek tünik, Walfish és $m t s a i[41]$ a teszt pszichometriai alkalmatlanságára hívják fel a figyelmet.

\section{Vélemény a pszichológiai értékelésről}

A pszichológiai vizsgálaton elhangzottakról a pszichológus rövid összefoglalót készít a sebész és az orvosi team számára. Ez tartalmazza a páciens táplálkozási szokásaival és súlyával s az ezek történetével kapcsolatos legfontosabb jellemzőket, az illető jelenlegi és múltbeli pszichiátriai problémáit, a teszteredményeket, a következtetéseket és a javaslatokat. Az alkalmasságra vonatkozóan Stevens és mtsai [10] az 1. táblázatban felsorolt javaslatokkal élnek.

Fontos hangsúlyozni, hogy a mütétnek számos pozitív hatása van, és kevés olyan pszichológiai tényező létezik, amely valóban kontraindikációt jelent a mútétre. A pszichológusnak tehát óvatosan kell bánnia minden olyan megjegyzéssel, amely megakadályozhatja a mútétet. Sokkal inkább érdemes finomítani a figyelmeztetést és hangsúlyozni azokat a feltúnő pszichés jellemzóket, amelyek nehézséget okozhatnak a kezelés során vagy utána. Tehát ha felmerül is bármilyen pszichológiai probléma, a mütétet általában javasoljuk, de úgy, hogy közben felhívjuk a sebész és a páciens figyelmét az esetleges nehézségekre. Így a végső döntést a sebész úgy hozhatja meg, hogy egyszerre tudja az orvosi, a táplálkozási és a pszichológiai faktorokat mérlegelni.

1. táblázat | Bariátriai mútétre való pszichológiai alkalmassági szempontok. Javaslatok Stevens és mtsai [10] alapján

\begin{tabular}{|c|c|c|}
\hline $\begin{array}{l}\text { Piros } \\
\text { (jelenleg nem alkalmas a mútétre) }\end{array}$ & $\begin{array}{l}\text { Sárga } \\
\text { (valószínúleg alkalmas a mútétre, de a kockázat } \\
\text { magasabb) }\end{array}$ & $\begin{array}{l}\text { Zöld } \\
\text { (mütétre alkalmas) }\end{array}$ \\
\hline $\begin{array}{l}\text { - Instabil pszichózis } \\
\text { - Aktív szerabúzus és alkoholfüggőség } \\
\text { - Súlyos/középsúlyos értelmi fogyatékosság } \\
\text { - Dementia } \\
\text { - Súlyos személyiségzavar } \\
\text { - Önsértés az elmúlt } 12 \text { hónapban } \\
\text { - Meglévő bulimia nervosa } \\
\text { - A kezelésekkel való együttmúködés hiánya }\end{array}$ & $\begin{array}{l}\text { - Súlyos mentális zavar: de a mentális állapot } \\
\text { stabil, az elmúlt } 12 \text { hónapban kórházi } \\
\text { felvétel vagy önsértés nem történt } \\
\text { - Alkohol- vagy szerabúzus vagy -függőség a } \\
\text { kórtörténetben } \\
\text { - Evészavar a kórtörténetben } \\
\text { - Enyhe értelmi fogyatékosság } \\
\text { - Alacsony fokú motiváció } \\
\text { - Nem realisztikus elvárások } \\
\text { - Falásrohamzavar } \\
\text { - Az evészavar összefüggéseivel kapcsolatos } \\
\text { nem megfelelő belátás } \\
\text { - Távolmaradás a kezelésekről, konzultációk- } \\
\text { ról } \\
\text { - Korábbi orvosi utasítások, kezelési terv be } \\
\text { nem tartása }\end{array}$ & $\begin{array}{l}\text { - Megfelelő motiváció } \\
\text { - A folyamat és a kimenetel megértése } \\
\text { - Megfelelő elvárások } \\
\text { - Betartott, kiegyensúlyozott étrend } \\
\text { - Az evéssel és a súlygyarapodással kapcsolatos } \\
\text { ismeretek, megfelelő belátás } \\
\text { - A kezeléssel való együttmúködés }\end{array}$ \\
\hline
\end{tabular}




\section{Következtetések}

A bariátriai mütét előtt álló páciensek pszichológiai alkalmasságának vizsgálata elengedhetetlen a hosszú távon is sikeres beavatkozás esélyének javítása érdekében. A pszichológusi vizsgálat segíthet megismerni a pontos motivációt, a döntés mellett húzódó tényezóket. A pszichológus feladata még, hogy megismerje, milyen tényezők fognak kihívást jelenteni a kezelés során, melyek azok az érzelmi faktorok, amelyek befolyásolják a mútéttel és annak következményeivel, valamint az életmódváltás nehézségeivel való megküzdést. A felmérés során a pszichológus egyszerre gyưjt adatokat, edukálja és motiválja a beteget, hogy realisztikus elvárásai legyenek, mindezt empatikus légkörben.

Bár egy ilyen felmérés a tesztfelvétellel együtt 2-2,5 órát is igénybe vehet, általa a mütét és a következmények szempontjából lényegi információkhoz jutunk. A konzultáció nemcsak a sebész, de a beteg számára is hasznos. Visszajelzést, megerősítést kaphat mentális állapotáról, és egy pszichológussal való pozitív tapasztalat ahhoz vezethet, hogy a páciens a későbbiekben szívesebben kér segítséget, ha nehézségekbe ütközik.

Anyagi támogatás: A közlemény megírása anyagi támogatásban nem részesült.

Szerzői munkamegosztás: T.-Sz. E.: Témafelvetés, a protokoll áttekintése és releváns részek lefordítása, saját példák írása, szakirodalom keresése és a cikk megírása. T. R.: Szakértői részvétel, szakirodalom keresése, kitekintések, a cikk megírása. A cikk végleges változatát mindkét szerző elolvasta és jóváhagyta.

Érdekeltségek: A szerzőknek nincsenek érdekeltségeik.

\section{Irodalom}

[1] WHO 2016 Global Health Observatory (GHO) data. Overweight and obesity. Available from: http://www.who.int/gho/ ncd/risk_factors/overweight_obesity/obesity_adults/en/ [accessed: September 10, 2018].

[2] Vasas P, Pór F. Current surgical options for reducing body weight. [A testsúlycsökkentés sebészi lehetőségei.] Orv Hetil. 2014; 155: 971-977. [Hungarian]

[3] Bene L. Invasive methods in the treatment of obesity. [Invaziv módszerek az elhízás kezelésében.] Orv Hetil. 2016; 157: 728732. [Hungarian]

[4] Lauti M, Kularatna M, Hill AG, et al. Weight regain following sleeve gastrectomy - a systematic review. Obes Surg. 2016; 26: 1326-1334.

[5] Flølo TN, Andersen JR, Kolotkin RL, et al. Five-year outcomes after vertical sleeve gastrectomy for severe obesity. A prospective cohort study. Obes Surg. 2017; 27: 1944-1951.

[6] Kinzl JF, Schrattenecker M, Traweger C, et al. Psychosocial predictors of weight loss after bariatric surgery. Obes Surg. 2006; 16: 1609-1614.

[7] Wadden TA, Sarwer DB, Fabricatore AN. Psychosocial and behavioral status of patients undergoing bariatric surgery: what to expect before and after surgery. Med Clin North Am. 2007; 91: 451-469.

[8] Fabricatore AN, Crerand CE, Wadden TA, et al. How do mental health professionals evaluate candidates for bariatric surgery? Survey results. Obes Surg. 2006; 16: 567-573.

[9] Snyder AG. Psychological assessment of the patient undergoing bariatric surgery. Ochsner J. 2009; 9: 144-148.

[10] Stevens T, Spavin S, Scholtz S, et al. Your patient and weight-loss surgery. Adv Psychiatr Treat. 2012; 18: 418-425.

[11] Czeglédi E. Motivation for weight loss among weight loss treatment participants. [A fogyás motivációi súlycsökkentő kezelésben részt vevók körében.] Orv Hetil. 2017; 158: 1960-1967. [Hungarian]

[12] Resch M. Dieting pitfalls - psychological factors. [A fogyókúrák buktatói - pszichés tényezők.] Orv Hetil. 2017; 158: 499-507. [Hungarian]

[13] Chao AM, Wadden TA, Faulconbridge LF, et al. Binge-eating disorder and the outcome of bariatric surgery in a prospective, observational study: two-year results. Obesity $2016 ; 24$ : 23272333.

[14] Wadden TA, Faulconbridge LF, Jones-Corneille LR, et al. Binge eating disorder and the outcome of bariatric surgery at one year: a prospective, observational study. Obesity 2011; 19: 12201228.

[15] Cox S, Brode C. Predictors of binge eating among bariatric surgery candidates: disinhibition as a mediator of the relationship between depressive symptoms and binge eating. Obes Surg. 2018; 28: 1990-1996.

[16] Dingemans AE, van Furth EF. Binge eating disorder psychopathology in normal weight and obese individuals. Int J Eat Disord. $2012 ; 45$ : 135-138.

[17] Wadden TA, Sarwer DB. Behavioral assessment of candidates for bariatric surgery: a patient-oriented approach. Surg Obes Relat Dis. 2006; 2: 171-179.

[18] Norris L. Psychiatric issues in bariatric surgery. Psychiatr Clin North Am. 2007; 30: 717-738.

[19] Pietiläinen KH, Kaprio J, Borg P. Physical inactivity and obesity: a vicious circle. Obesity 2008; 16: 409-414.

[20] Long SJ, Hart K, Morgan LM. The ability of habitual exercise to influence appetite and food intake in response to high- and lowenergy preloads in man. Br J Nutr. 2002; 87: 517-523.

[21] Silveira H, Moraes H, Oliveira N, et al. Physical exercise and clinically depressed patients: a systematic review and meta-analysis. Neuropsychobiology 2013; 67: 61-68.

[22] Josefsson T, Lindwall M, Archer T. Physical exercise intervention in depressive disorders: meta-analysis and systematic review. Scand J Med Sci Sports 2014; 24: 259-72.

[23] Miller WC, Koceja DM, Hamilton EJ. A meta-analysis of the past 25 years of weight loss research using diet, exercise or diet plus exercise intervention. Int J Obes Relat Metab Disord. 1997; 21 : 941-947.

[24] Thorogood A, Mottillo S, Shimony A, et al. Isolated aerobic exercise and weight loss: a systematic review and meta-analysis of randomized controlled trials. Am J Med. 201 1; 124: 747-755.

[25] King NA, Horner K, Hills AP, et al. Exercise, appetite and weight management: understanding the compensatory responses in eating behaviour and how they contribute to variability in exerciseinduced weight loss. Br J Sports Med. 2012; 46: 315-322.

[26] Turner P, Williams C. Informed consent: patients listen and read but what information do they retain? N Z Med J. 2002; 115: $\mathrm{U} 218$.

[27] Hutson MM, Blaha JD. Patients' recall of preoperative instruction for informed consent for an operation. J Bone Joint Surg Am. 1991; 73: 160-162.

[28] Robinson G, Merav A. Informed consent: recall by patients tested postoperatively. Ann Thorac Surg. 1976; 22: 209-212. 
[29] Sahin N, Oztürk A, Ozkan Y, et al. What do patients recall from informed consent given before orthopedic surgery? Acta Orthop Traumatol Turc. 2010; 44: 469-475.

[30] Kalarchian MA, Marcus MD, Levine MD, et al. Psychiatric disorders among bariatric surgery candidates: relationship to obesity and functional health status. Am J Psychiatry 2007; 164: 328334

[31] Odom J, Zalesin KC, Washington TL, et al. Behavioral predictors of weight regain after bariatric surgery. Obes Surg. 2010; 20: 349-356.

[32] Pelchat ML. Food addiction in humans. J Nutr. 2009; 139: 620622.

[33] Gustafson TB, Sarwer DB. Childhood sexual abuse and obesity. Obes Rev. 2004; 5: 129-135.

[34] Irish L, Kobayashi I, Delahanty DL. Long-term physical health consequences of childhood sexual abuse: a meta-analytic review. J Pediatr Psychol. 2010; 35: 450-461.

[35] Danese A, Tan M. Childhood maltreatment and obesity: systematic review and meta-analysis. Mol Psychiatry 2014; 19: 544554.

[36] Hemmingsson E, Johansson K, Reynisdottir S. Effects of childhood abuse on adult obesity: a systematic review and meta-analysis. Obes Rev. 2014; 15: 882-893.
[37] Noll JG, Zeller MH, Trickett PK, et al. Obesity risk for female victims of childhood sexual abuse: a prospective study. Pediatrics 2007; 120: e61-e67.

[38] Butcher JN, Graham JR, Ben-Porath YS, et al. MMPI-2: Manual for administration and scoring. (Rev. ed.) University of Minnesota Press, Minneapolis, Minnesota 2001.

[39] Millon T, Antoni MH, Millon C, et al. Test manual for the Millon Behavioral Medicine Diagnostic (MBMD). National Computer Services, Minneapolis, MN, 2001.

[40] Pressing L, Szakács F. New Hungarian standards of MMPI. [Az MMPI-próba új magyar standardja.] A Társadalmi beilleszkedési zavarok címú kutatás Programirodája, Budapest, 1990. [Hungarian]

[41] Walfish S, Wise EA, Streiner DL. Limitations of the Millon Behavioral Medicine Diagnostic (MBMD) with bariatric surgical candidates. Obes Surg. 2008; 18: 1318-1322.

(Tisljár-Szabó Eszter dr., Debrecen, Móricz Zs. krt. 22., 4032 e-mail: eszter.szabo@sph.unideb.hu)

\section{"Similis simili gaudet." \\ (Hasonló a hasonlót kedveli.)}

\section{PÁLYÁZATI FELHÍVÁS}

Dr. Fehér Jánosnak, a Semmelweis Egyetem II. sz. Belgyógyászati Klinika volt igazgatójának és az Orvosi Hetilap volt föszerkesztőjének emlékére létrehozott Dr. Fehér János Emlékére Alapítvány minden évben pályázatot ír ki egyetemi hallgatók, fiatal egyetemi oktatók és $\mathrm{PhD}$-hallgatók részére, akik a belgyógyászatban, különösen a hepatológiában végzett kutatási eredményeiket az Orvosi Hetilapban publikálják.

A kéziratot „Dr. Fehér János pályázat” megjelöléssel 2019. április 15-ig kell feltölteni az Orvosi Hetilap Editorial Manager rendszerébe.

A pályázathoz mellékelni kell a pályázó önéletrajzát.

A díj odaítéléséről az Alapítvány kuratóriuma dönt. A díj átadására a Markusovszky Lajos-ünnepségen, 2019. májusában kerül sor, ahol a nyertes pályázó rövid előadásban ismertetheti eredményeit.

A cikk a Creative Commons Attribution 4.0 International License (https://creativecommons.org/licenses/by/4.0/) feltételei szerint publikált Open Access közlemény, melynek szellemében a cikk bármilyen médiumban szabadon felhasználható, megosztható és újraközölhetö, feltéve, hogy az eredeti szerző és a közlés helye, illetve a CC License linkje és az esetlegesen végrehajtott módosítások feltüntetésre kerülnek. (SID_1) 